A. O. Kyselov, Cand. Sc. (Jurid.), orcid.org/0000-0003-3106-4376

Dnipropetrovsk State University of Internal Affairs, Dnipro, Ukraine, e-mail: dduvs@email.ua

\title{
COMBATING ILLEGAL AMBER MINING: PECULIARITIES OF CONFLICT RESOLUTION
}

Purpose. Identification and analysis of tactical rules of conflict-free communication of criminal police officers of the National Police of Ukraine with any persons in the process of combating illegal amber mining.

Methodology. The author used the analytical method and problem-subject method. Opinions of specialists, scientific-theoretical and practical issues in the field of psychology were systematized in order to determine the causes and discover the essence of the conflict during communication.

Findings. The paper defines the influence of the causes of conflict during combating illegal amber mining on the course and results of communication, followed by identifying the most effective conditions for resolution and ending of the conflict. Psychological characteristics of communication were analyzed, and it was found that the knowledge of the rules of communication by the participants represented the most important condition of its effectiveness.

Originality. The legal and psychological aspects of the conflict are adapted to situations of countering the illegal amber mining. Actions taken according to results of the study will contribute to putting the amber mining process in the legal framework, and improving the crime situation in the region where these minerals occur. The legal basis for taking the opportunities of confidential cooperation by the criminal police officers of the National Police of Ukraine was determined.

Practical value. Usage of the relevant rules of communication will allow making such communication conflictfree. Tactically built communication is the key to conflict-free, meaningful and productive dialog of the criminal police officer of the National Police of Ukraine with any persons in the course of countering the illegal amber mining. Improvement of the tactics of communication with people while countering illegal amber mining in general and confidential cooperation in particular will allow the officers of criminal police units to increase the efficiency of combating and preventing crime based on the mechanisms proposed in this study. Implementation of the work results will improve quality of the investigation of criminal proceedings, and raise the level of compensation of damages caused by illegal activities. It will have positive effect on the economic component by reducing the volumes of criminal consequences of the illegal amber mining.

Keywords: illegal amber mining, conflict-free communication, conflict resolution, conflict prevention, criminal intelligence units, rules and purposes of communication

Introduction. The strategy of economic development of any state stipulates the increased attention to the process of accumulation of mineral resources involving the subsurface use. It means mining and processing of metallic, nonmetallic and combustible mineral resources, with the significant importance given to mining of precious stones, in particular, amber raw materials. According to the Ukrainian legislation, it is in the category of jewelry materials. Commercialization of this field of activities is often accompanied by illegal actions causing severe damage to the national economy and environmental safety [1].

Crimes in the field of subsurface use in Ukraine are characterized by continuous growth and high latency. Illegal amber mining results in changes in the hydrological regime, deterioration of topsoil and vegetation. Damage to fertile soil layer prevents further effective use of soil. The consequences of the above are significant losses incurred by the state.

The problem of illegal amber mining to date remains relevant for some regions of our country. State enterprises of Ukraine officially engaged in amber mining are not profitable from an economic point of view. At the same time, illegal amber mining and sales, including sales abroad, bring high profits bypassing the state budget.

(C) Kyselov A. O., 2019
All methods of committing violations of the rules of subsurface resources protection are divided into two groups:

- illegal mining in open workings;

- illegal mining using underground method.

With regard to raw amber mining, almost in all cases the criminals use surface mining method. Illegal way of surface mining consists in the removal of amber from the top layers of its occurrence.

It terms of equipment, illegal amber mining can be both simple and complex.

Simple equipment supposes the use of the simplest tools by criminals (picks, shovels, winches and others) for amber mining.

Complex mining equipment includes the compound mechanisms, in particular, process units (specially mounted compressor, water pump), and specialized machinery (excavators, bulldozers, and others) [1] for extraction of amber from its deposits.

Units of criminal police of the National Police of Ukraine are the subjects countering the illegal amber mining. It appears that the activity of criminal police units for combating the illegal amber mining will be effective on condition of the interaction with citizens. Presence of persons cooperating with criminal police units, including such cooperation on confidentiality basis, is an essential element of countering the illegal amber mining. 
Analysis of the recent research and publications. Studies of problematic issues of the operational-investigative activities of criminal intelligence units in the course of crime prevention were conducted by the scientists such as K. V. Antonov, V. V. Darahan, E. O. Didorenko, O. F. Dolzhenkov, A. V. Yefremov, B. A. Kernytskyi, O. V. Kyrychenko, I. P. Kozachenko, V. A. Nekrasov, D. Y. Nykyforchuk, S. V. Obshalov, V. L. Ortynskyi, I. M. Okhrimenko, Ye. V. Ryzhkov, I. V. Servetskyi, Ya. I. Slobodian, V. Ye. Tarasenko, R. V. Tarasenko, Yu. E. Cherkasov, I. R. Shynkarenko and others.

Psychological features of communication, including conflict-free communication, were studied by the experts in the field of psychology such as D.O.Aleksandrov, L. V. Balabanova, B. I. Baranenko, L. V. Batlyna, O. I. Bohucharova, M. Y. Varii, P.A. Honcharuk, A. T. Ishmuratov, V. M. Komarnytskyi, V. O. Konovalova, V. O. Kryvolapchuk, S. D. Maksymenko, R. S. Nemov, N. D. Parkhomenko, L. G. Podoliak, V. V. Rybalka, K. V. Savelieva, R. K. Seriozhnykova, V. O. Solovienko, L. D. Stoliarenko, Yu.L.Trofimov, I. M. Tsymbaliuk, Yu. G. Shadskykh, V. Yu.Shepitko, V.I. Yurchenko, L.S. Yakovytska and others.

Taking into account specific nature of operationalinvestigative activities and individual characteristics of people to communicate with, the tactical rules of communication of criminal police officers with such people in the course of the above activities should be determined and considered in detail.

Objectives of the article. The purpose of this paper is the identification and analysis of tactical rules of conflict-free communication of the criminal police officers of the National Police of Ukraine with any persons during combating the illegal amber mining.

Presentation of the main research and explanation of scientific results. According to the Law of Ukraine "On the State Regulation of Mining, Production and Use of Precious Metals and Precious Stones and Control over Transactions with Them", raw amber (in raw condition and processed condition) refers to precious stones [2]. Therefore, for amber mining a special permit is required. In Ukraine, the large amounts of amber have been mined by prospectors on illegal sites under control of organized criminal gangs for decades.

Taking into account the urgency of illegal amber mining in Ukraine, and no relevant changes made to the laws, it is appropriate to counter such crimes more effectively with the use of available resources of the National Police.

Actions of public authorities in the society are governed according to the requirements and functions performed by these authorities. Since operative-investigative activity and its main component, i.e. confidential cooperation, is a public activity, the legal regulation of it is subject to the requirements relating to such activities [3].

On condition of the active use of opportunities of confidential cooperation, the criminal intelligence units of the National Police will effectively perform their tasks. While carrying out operational-investigative activities, the officers of the criminal intelligence units of the National Police are guided by the Constitution and
Laws of Ukraine, and the regulatory acts of the MIA of Ukraine. It is the basis for the legal use of opportunities of confidential cooperation by such units.

The legal base for confidential cooperation of any persons with the officers of the criminal intelligence units of the National Police in general and in the course of combatting the illegal amber mining, in particular, includes the Constitution of Ukraine [4], Laws of Ukraine "On the National Police" [5], "On the Operational-Investigative Activities" [6], "On the Organizational and Legal Framework to Combat the Organized Crime" [7], "On the State Protection of Employees of Courts and Law Enforcement Agencies" [8], "On Protection of Individuals Involved in Criminal Proceedings" [9], "On Information" [10], the Criminal Code and the Code of criminal procedure of Ukraine [11, 12], other legislative acts of Ukraine.

For example, Article 11 of the Law of Ukraine "On the National Police" states that the police acts in close cooperation and interaction with citizens, territorial communities and public associations on the basis of partnership with the aim of satisfying their needs [5].

According to Article 8 of the Law of Ukraine "On Operational-Investigative Activities", the criminal intellgence units have the right to involve overt and covert staff members and non-staff employees (p. 13), use the confidential cooperation under Article 275 of the Code of criminal procedure of Ukraine (p. 14), and perform special tasks of disclosing criminal activities of organized criminal gangs or criminal organizations under Article 272 of the Code of criminal procedure of Ukraine (p. 8) [6].

However, the criminal intelligence units of the National Police should use the opportunities of confidential cooperation only when solving the issued referred to their competence. Consequently, this type of cooperation is exceptional by its nature. The law provides that using of the confidential cooperation for any other purposes is prohibited. Actions of persons having no authority to conduct operational-investigative activities should be regarded as unlawful.

The criminal police officers involved in the operational-investigative activities communicate mostly with the persons who are preparing for a crime, or have committed the crime, resulting in conflicting nature of such communication. Therefore, it is necessary to determine the tactical rules of conflict-free communication of the officers of criminal police in their operational-investigative efforts.

The word "conflict" (from Latin conflictus) translated literally means a collision. Essence of the conflict is determined as a lack of agreement between two or more parties (Balabanova L.V., Savelieva K. V.).

D. Moreno (2004) distinguishes two structures of relations:

1) macrostructure ("spatial" placement of individuals in various forms of their life);

2) microstructure (structure of psychological relationship of an individual with other people).

According to Moreno, all conflicts are caused by mismatch of the micro- and macrostructure. 
In the course of work, we analyzed the causes of conflicts in the process of countering the illegal amber mining and their connection with the psychological aspects of communication.

The criminal police officer, when communicating with any persons during his/her operational-investigative activities in general and combating the illegal amber mining in particular, should keep the progress and results of communication under control, being able to properly complete the interaction, forming a partner's relevant (good or bad) idea of him/herself, and getting the person to want/ not to want to continue the dialog.

Accordingly, psychologically optimal communication is the communication where intentions of participants are realized pursuant to the motives which condition such intentions, and using the means not resulting in the partners' feeling of dissatisfaction. Psychologically optimal communication can be also achieved when the partners can keep the subjective distance desirable for each of them. Since communication is an interaction of at least two persons, the difficulties in its course (i.e. subjective difficulties) can be produced by one of the parties or both. Psychological reasons can include unrealistic objectives, inadequate assessment of a partner, his/her abilities and interests, misconceptions of their own capabilities and lack of understanding of the partner's assessment and attitude, as well as the use of means of approaching the partner which are not suitable for the situation.

Interpersonal space (communication distance) between the police officer and any person he/she communicates with is extremely important. The distance of communication depends on many factors: the direction of communication, various characteristics of the subjects of communication (their affinity, age, social status, mental features, national customs and others).

According to American psychologists, the distance between partners depends on the type of interaction, as detailed below:

- intimate distance (corresponds to intimate relations) - up to $0.5 \mathrm{~m}$;

- interpersonal distance (in interviews, communication with friends) $-0.5-1.2 \mathrm{~m}$;

- social distance (typical for informal social and business relationship) $-1.2-3.7 \mathrm{~m}$;

- public distance $-3-7 \mathrm{~m}$ and more.

In the course of any communication, a distance chosen correctly has a significant effect on its course. It can be assumed that the distance during communication of the police officer with any persons during the operational-investigative activities should not come into the range of intimate distance and, at the same time, not exceed the upper limit of social distance range.

We know that a person is firstly judged by the way he/she looks, and it means, among other things, clothing, but not principally. First of all, the source of information is the human body, the eyes, arms, shoulders, manner of walking and many other factors combined under the word "appearance".

During visual contact the eyes can say much more than words. Eye contact helps to regulate the conversation.
Psychological research shows that $40 \%$ of information is borne by gestures and facial expressions.

Gestures include all hand gestures ("language of hands") and some other actions which render certain meaning.

Facial expressions include any changes which can be seen on the face of a person, and it is not just about features, eye contact and direction of the glance, but also psychosomatic processes (e.g., flushing).

Consideration of all factors of nonverbal communication is extremely important in conflict-free communication of the police officer with any persons. Sometimes any gestures or facial expressions can give important information to both parties of communication. Success of communication to some extent depends on the knowledge of different nuances of nonverbal communication by the communicating parties (especially, police officers). The work of L. G. Podoliaka (2006) includes some examples of interpreting nonverbal behavior during negotiations which can be taken into account by criminal police officers when dealing with people in the process of combatting the illegal amber mining.

1. Holding "the arms crossed on the breast" means the defense position - the negotiations should not be finished (as a conclusion).

2. "The partner slightly knocks on the table" means impatience - the negotiations should be finished.

3. "Steepling palms, or fingers" mean the sense of superiority; the partner considers him/herself smarter possibly, the negotiations should be finished.

4. "The partner rubs his/her eyes" means distrust it is worth thinking.

5. "The head slightly tilted to a side" means peace and satisfaction - the negotiations can be finished.

6. "Intent look with the head lifted, or tilted" means "Wait a minute, I'll think" - the contact should be interrupted.

7. "Movement of the head, with brows knitted" means "I do not understand, repeat, please" - the contact should be enhanced.

8. "Smile, with the head slightly tilted" means "I understand, and have nothing to add" - the contact is maintained.

9. "Rhythmic nodding of the head" means "I clearly understand what you need" - the contact is maintained.

10. "Long intent look in partner's eyes" means the intention of conquering the partner - it is necessary to act according to circumstances.

11. "Looking the other way" can mean the neglect the partner avoids contact.

12. "Looking at the floor" means the fear and intention to avoid contact.

Referring to the subject of illegal amber mining, which is performed or controlled by organized criminal organizations, it is worth noting the existence of intergroup conflicts in the current criminal environment that occur most often between different powerful organized criminal gangs. They are the most complex and highprofile conflict phenomena.

Generally, these conflicts originate from the system of intergroup interaction between the groups of persons, 
individual members of groups and other participants of interaction as well, where the parties see each other as members of different groups.

The problem of studying the conflict phenomena in the organized criminal environment is of both theoretical and practical importance. Thus, referring to the knowledge of conflicts that arise in organized gangs and criminal organizations, it should be noted that, on condition of the certain scenarios, they themselves lead to undermining of the integrity of these formations, loss of understanding among their members, occurrence of antagonism, hostility between them etc. which with their further aggravation may cause the destruction of the said formations.

Apparently, these patterns can be used in operational-investigative activities, especially for the purpose of operational and preventive separation of criminal groups, their disclosure, detection, suppression, investigation of crimes committed by them, and so on.

Timely obtaining of information by the intelligence officers regarding the course of conflict resolution in the criminal environment allows intervening in these processes intelligently, directing them towards performance of the tasks of operational-investigative activity.

The practical importance of the knowledge of conflicts in the criminal environment consists also in the following:

- firstly, conflicts fulfil the important information function for operational-investigative activities, because they are carriers of essential information about contradictions in the criminal environment, their parties and positions occupied by them;

- secondly, in some operational and tactical situations conflicts can be used as prerequisites for establishing contact with the objects of interest in the investigative operations and further development of constructive interaction with them (Alexandrov D. O., Baranenko B. I., at al.).

In the course of work, we analyzed the causes of conflicts in the process of countering the illegal amber mining and their connection with the psychological aspects of communication. We analyzed and summarized some rules of conflict-free communication. They are adapted to the situation of illegal amber mining, and the following recommendations are developed in this regard.

In order to ensure conflict-free communication, for the criminal police officer it is appropriate to:

- try to look confident, behave with dignity, and optimistically;

- have a nice smile, frank look, keep the facial expression friendly;

- maintain a good posture during the conversation, not to slouch when standing;

- keep hands calmly and freely;

- slightly lean towards the partner at the time of communication;

- be attentive and alert, ready to any difficulties which may affect the course of communication;

- maintain high activity in communication.

Along with these, it is inappropriate to:

- look defeated, hunched, frowning;
- keep the head lowered and look out of the corners of eyes;

- sit leaning back;

- keep the legs crossed;

- rub the hands nervously;

- demonstrate superiority, ignore the partner;

- look indifferent;

- look at the floor;

- pull the pen, handkerchief or twist glasses in the hands;

- rhythmically tap the fingers on the table;

- shift nervously in the chair;

- touch and stroke the hair by hand;

- chew the gum;

- scratch oneself, and others.

The dialog as the form of conflict-free, meaningful and productive communication is worth detailed consideration. The dialog is based on trust and respect for each other. It is necessary to show confidence in solving the problem. You can always find some ways to fix it, so it is important to direct attention to a common goal; desire to find agreement in its achievement. A great deal of help is given by the approach to matters using which you can make the people speak with an open heart.

The dialog is a good method of influencing the mind of a person, and it can be successfully used if of the following rules are observed:

1. Timely choice of the role of the speaker/listener.

2. Ability to listen to the partner.

3. Ability to give the proper form to one's understanding (criticizing the person's actions, instead of the person him/herself).

Effective communication depends on many factors. We recommend you to follow the rules necessary for the criminal police officer to make a good impression on people and to avoid unnecessary conflicts.

1. Show genuine interest in other people.

2. Try to understand the other person's strengths and welcome them sincerely. Allow the other person to feel his/her significance.

3. Instead of condemning others, try to understand what makes them do so. It is more effective than criticism.

4. Try to be friendly and kind, keep smiling.

5. Refer to a person by his/her name. It is the most important and pleasant for the person to hear his/her name.

6. Take into account the desires, tastes and interests of your partner; keep the conversation within his/her preferences.

7. Learn to be a good listener, encourage others to tell about themselves.

8. Respect the other people's opinion; avoid telling the people that they are wrong.

9. Give a partner the opportunity to speak out; most people, trying to convince the other person of anything, talk too much. Avoid interrupting the partner even if you do not agree with him/her.

10. Try to see most things from the perspective of another person, put yourself in his/her position. 
With this in mind, it is possible to provide the following tips to the criminal police officer with regard to conducting a dialog:

- speak convincingly and beautifully;

- speak only when you have something to say;

- speak briefly and accurately;

- speak to be heard;

- do not use obscure words;

- speak to interest the others;

- use less gestures;

- do not moralize in the dialog;

- try to keep confidence even in challenging situations;

- do not succumb to emotions and others.

When it is not possible to prevent a conflict, it is necessary to resolve it constructively. Resolution of the conflict comprises the joint efforts of its participants, aimed at ending of controversies and solving of the problem that led to collision. Conflict resolution involves the activity of both parties to transform the environment in which they interact, and eliminate the causes of conflict. Resolution of the conflict implies its termination.

In order to solve the problem and reach the agreement, participants of the conflicts enter into negotiations and review their own positions. This method of problem solving is called the compromise. As stated by A. T. Ishmuratov (1996), psychological compromise is a natural attempt to change the person's mind, making a step towards the other person for going out of the conflict.

During interpersonal conflict with any person, the criminal police officer should observe the following rules of conduct:

1. Keep calm and cool.

2. Determine the nature of the conflict, its cause.

3. Avoid personal collisions with the partner.

4. Avoid the words with the negative content in terms of emotional evaluation.

5. Understand the position, views and interests of a person.

6. Stay open to consideration of mutual claims and suggestions.

There are some recommendations on the use by intelligent officers of certain rules of personal behavior that can help to avoid unexpected aggravation of the conflict during operational communication. In particular, in such cases one should adhere to the following:

1) find and eliminate the main cause of conflict, or move the negative emotions which may arise towards any foreign object of the controversy;

2) do not ignore the objective reasons leading to the conflict during the operational communication, trying to find a peaceful solution on the basis of position of the operational communication object;

3) do not resort to volition pressures in the conflict; try to use the reasoned arguments;

4) do not use offensive language, especially towards personal characteristics of the partner, because it can lead to psychological "explosion";

5) always try to neutralize the excessive emotionality of the conflict;
6) in case of your own (or partner's) nervousness, terminate and postpone the conversation.

Always remember that the conflict is, first of all, a signal of unresolved problems arising in the relations with the corresponding object during the operational communication and the problem should be analyzed, understood and solved, if the purpose of communication is important and is not reached yet.

Conclusions. According to the results of the research, the author determined the impact of causes of the conflict during the process of countering the illegal amber mining on the course and results of communication, with the further identification of the most effective conditions for resolving and elimination of the conflict situation. For the first time, the legal and psychological aspects of the conflict are adapted to situations of countering the illegal amber mining.

The legal base for confidential cooperation of any persons with the criminal police officers of the National Police of Ukraine in the course of combatting the illegal amber mining is the aggregate of legal regulations contained in the legislative acts which govern the process of confidential cooperation of persons with the criminal intelligence units, their rights and obligations; determine the guarantees of legality in such activity, social and legal protection of persons involved in the confidential cooperation.

Officers of the criminal police should make every effort to prevent conflicts with people while combating the illegal amber mining, using the above rules of conflictfree communication, rather than allow occurrence of conflicts. In case of any conflict it is also proposed to observe the rules, which may lead to the constructive termination of the conflict.

Improvement of the tactics of communication with people while countering illegal amber mining and confidential cooperation will allow the officers of criminal police units to increase the level of efficiency of combating and preventing crime based on the mechanisms proposed in this study.

Implementation of the work results will improve quality of the investigation of criminal proceedings, and raising the level of compensation of damages caused by illegal activities. It will have positive effect on the situation connected with the illegal amber mining.

\section{References.}

1. Tatarov, O. Yu. and Marco, S. I., 2014. Forensic characterization of violations of safety or subsoil use rules on example of illegal amber extraction. Naukovyi Visnyk Lvivskoho Derzhavnoho Universytetu Vnutrishnikh Sprav, Legal series, 3, pp. 273-285.

2. Legislation of Ukraine, 2017. On the State Regulation of Mining, Production and Use of Precious Metals and Precious Stones and Control over Transactions with Them. Law of Ukraine as of 18.11.1997 [online]. Available at: <http://zakon.rada.gov.ua/laws/show/637/97-BP> [Accessed 21 September 2017].

3. Usenko, V. F., Nekrasov, V.A. and Matsiuk, V. Ya, 2007. Use of confidential assistance of citizens in crime prevention. Monograph. KKNT. 
4. Legislation of Ukraine, 2017. The Constitution of Ukraine. Law as of 28.06.1996 [online]. Available at: <http://zakon.rada.gov.ua/laws/show/254K/96Bphttp://zakon.rada.gov.ua/laws/show/637/97-BP> [Accessed 15 September 2017].

5. Legislation of Ukraine, 2017. On the National Police. Law of Ukraine as of 02.07.2015 [online]. Available at: <http://zakon.rada.gov.ua/laws/show/580-VIIIhttp:// zakon.rada.gov.ua/laws/show/637/97-BP> [Accessed 11 November 2017].

6. Legislation of Ukraine, 2017. On the Operational-Investigative Activity. Law of Ukraine as of 18.02.1992 [online]. Available at: <http://zakon.rada.gov.ua/laws/ show/2135-XII > [Accessed 3 October 2017].

7. Legislation of Ukraine, 2017. On the Organizational and Legal Framework to Combat the Organized Crime. Law of Ukraine as of 30.06.1993 [online]. Available at: <http://zakon.rada.gov.ua/laws/show/3341-XII> [Accessed 7 November 2017].

8. Legislation of Ukraine, 2017. On the State Protection of Employees of Courts and Law Enforcement Agencie. Law of Ukraine as of 23.12.1993 [online]. Available at: <http://zakon.rada.gov.ua/laws/show/3781-XII> [Accessed 7 December 2017].

9. Legislation of Ukraine, 2017. On Protection of Individuals Involved in Criminal Proceedings. Law of Ukraine as of 23.12.1993 [online]. Available at: <http://zakon.rada.gov. ua/laws/show/3782-XII> [Accessed 22 October 2017].

10. Legislation of Ukraine, 2018. On Information. Law of Ukraine as of 02.10.1992 [online]. Available at: <http:// zakon.rada.gov.ua/laws/show/2657-XII> [Accessed 5 January 2018].

11. Legislation of Ukraine, 2018. The Criminal code of Ukraine as of 05.04.2001 [online]. Available at: <http:// zakon.rada.gov.ua/laws/show/2341-III > [Accessed 22 April 2018].

12. Legislation of Ukraine, 2017. The Code of criminal procedure of Ukraine as of 13.04.2012 [online]. Available at: <http://zakon.rada.gov.ua/laws/show/4651VI $>$ [Accessed 21 September 2017].

\section{Протидія незаконному видобутку бурштину: особливості вирішення конфліктних ситуацій}

\section{А.О.Кисельов}

Дніпропетровський державний університет внутрішніх справ, м. Дніпро, Україна, e-mail: dduvs@email.ua

Мета. Визначення та аналіз тактичних правил безконфліктного спілкування працівників кримінальної поліції Національної поліції України з особами під час протидії незаконному видобутку бурштину.

Методика. Були використані метод аналізу та проблемно-тематичний метод. Систематизовані погляди фахівців, а також науково-теоретичні й сучасні практичні питання в галузі психології, що дозволяють встановити причини та розкрити сутність конфлікту під час спілкування.
Результати. Визначено вплив причин конфлікту під час протидії незаконному видобутку бурштину на хід і результати спілкування, з подальшим виявленням найбільш ефективних умов вирішення й завершення конфліктної ситуації. Проаналізовані психологічні особливості спілкування, встановлено, що найбільш важливими умовами його ефективності є знання учасниками правил спілкування.

Наукова новизна. Полягає в тому, що правові та психологічні аспекти конфлікту адаптовані до ситуацій протидії незаконному видобутку бурштину. Дії за результатами дослідження сприятимуть уведенню процесу видобутку бурштину у правове поле, покращенню криміногенної обстановки в регіоні залягання цих корисних копалин. Визначена правова основа використання працівниками кримінальної поліції Національної поліції України можливостей конфіденційного співробітництва.

Практична значимість. Використання відповідних зазначених правил спілкування дозволить зробити вказане спілкування безконфліктним. Тактично правильно побудоване спілкування є запорукою безконфліктного, конструктивного та продуктивного спілкування працівника кримінальної поліції Національної поліції України з особами під час протидії незаконному видобутку бурштину. Удосконалення тактики спілкування з особами під час протидії незаконному видобутку бурштину взагалі та конфіденційного співробітництва зокрема дозволить працівникам підрозділів кримінальної поліції, на основі запропонованих у дослідженні механізмів, підвищити рівень ефективності протидії та запобігання злочинам. Упровадження результатів роботи сприятиме покращенню якості розслідування кримінальних проваджень, підвищенню рівня відшкодування збитків, заподіяних протиправною діяльністю, що позитивно вплине на економічну складову шляхом зменшення кількості та обсягів злочинних наслідків незаконного видобутку бурштину.

Ключові слова: незаконний видобуток бурштину, безконфліктне спілкування, вирішення конфлікту, запобігання конфліктові, оперативні підрозділи, правила та цілі спілкування

\section{Противодействие незаконной добыче янтаря: особенности решения конфликтных ситуаций}

\section{A. А. Киселев}

Днепропетровский государственный университет внутренних дел, г. Днепр, Украина, e-mail: dduvs@email.ua

Цель. Определение и анализ тактических правил бесконфликтного общения работников криминальной полиции Национальной полиции Украины с лицами во время противодействия незаконной добыче янтаря.

Методика. Были использованы метод анализа и проблемно-тематический метод. Систематизированы взгляды специалистов, а также научно-теоре- 
тические и совеменные практические вопросы в области психологии, позволяющие установить причины и раскрыть сущность конфликта во время общения.

Результаты. Определено влияние причин конфликта во время противодействия незаконной добыче янтаря на ход и результаты общения, с последующим выявлением наиболее эффективных условий решения и завершения конфликтной ситуации. Проанализированы психологические особенности общения, установлено, что наиболее важным условием его эффективности является знание участниками правил общения.

Научная новизна. Заключается в том, что правовые и психологические аспекты конфликта адаптированы к ситуациям противодействия незаконной добыче янтаря. Действия по результатам исследования будут способствовать введению процесса добычи янтаря в правовое поле, улучшению криминогенной обстановки в регионе залегания этих полезных ископаемых. Определена правовая основа использования работниками криминальной полиции Национальной полиции Украины возможностей конфиденциального сотрудничества.

Практическая значимость. Использование соответствующих указанных правил общения позволит сделать данное общение бесконфликтным. Тактиче- ски правильно построенное общение является залогом бесконфликтного, конструктивного и продуктивного общения работника криминальной полиции Национальной полиции Украины с лицами во время противодействия незаконной добыче янтаря.

Совершенствование тактики общения с лицами во время противодействия незаконной добыче янтаря вообее и конфиденциального сотрудничества в частности позволит работникам криминальной полиции, на основе предложенных в исследовании механизмов, повысить уровень эффективности противодействия и предотвращения преступлений. Внедрение результатов работы будет способствовать улучшению качества расследования уголовных производств, повышению уровня возмещения ущерба, причиненного противоправной деятельностью, что положительно повлияет на экономическую составляющую путем уменьшения количества и объемов преступных последствий незаконной добычи янтаря.

Ключевые слова: незаконная добыча янтаря, бесконфликтное общение, решение конфликта, предотвращение конфликта, оперативные подразделения, правила и цели общения

Рекомендовано до публікації докт. юрид. наук I. В. Пирогом. Дата надходження рукопису 11.09.17. 